\title{
Improving Science Learning Outcomes Through the SETS (Science Environment Technology And Society) Approach
}

\author{
Widiastuti, N.L.G.K ${ }^{1 *}$, Purnawijaya, I.P.E ${ }^{2 *}$ (iD) \\ 1,2,3 Pendidikan Guru Sekolah Dasar, Universitas Dwijendra, Bali, Indonesia \\ *Corresponding author: jummita11@gmail.com
}

\begin{abstract}
Abstrak
Pengemasan pembelajaran IPA masih berfokus pada pembelajaran konvensional. Hal ini menyebabkan siswa merasa bosan dalam belajar dan kesulitan memahami materi yang diajarkan oleh guru. permasalahan ini berpengaruh pada hasil belajar IPA siswa yang rendah. Penelitian ini bertujuan untuk menganalisis perbedaan signifikan hasil belajar IPA kelompok siswa yang dibelajarkan melalui penerapan pendekatan SETS dan siswa yang dibelajarkan melalui pembelajaran konvensional. Jenis penelitian ini adalah eksperimen semu dengan desain penelitian nonequivalent control group design. Populasi dan sampel pada penelitian ini adalah seluruh siswa kelas IIIa dan IIIb yang berjumlah 61 orang. Teknik pengumpulan data pada penelitian adalah tes. Teknik yang digunakan untuk menganalisis data menggunakan analisis statistik uji-t. Hasil penelitian menunjukkan bahwa terdapat perbedaan yang signifikan hasil belajar IPA antara kelompok eksperimen dan kontrol yang dilihat dari nilai thitung $=5,862>\mathrm{t}_{\text {tabel }}=2,000$. Berdasarkan hasil penelitian dapat disimpulkan bahwa pendekatan SETS berpengaruh terhadap hasil belajar IPA siswa. Implikasi dari penelitian ini yaitu pendekatan SETS dapat membantu guru dalam mengembangkan proses pembelajaran.
\end{abstract}

Kata kunci: Pendekatan SETS, Hasil Belajar, IPA

\section{Abstract}

Science learning packaging still focuses on conventional learning. This causes students to feel bored in learning and have difficulty understanding the material taught by the teacher. This problem affects the students' low science learning outcomes. This study aims to analyze the significant differences in science learning outcomes for groups of students who are taught through the application of the SETS approach and students who are taught through conventional learning. This type of research is a quasi-experimental research design with nonequivalent control group design. The population and sample in this study were all students in grades IIIa and IIIb, totaling 61 people. The data collection technique in this research is a test. The technique used to analyze the data is using t-test statistical analysis. The results showed that there was a significant difference in science learning outcomes between the experimental and control groups as seen from the value of tcount $=$ $5.862>$ ttable $=2,000$. Based on the results of the study, it can be concluded that the SETS approach has an effect on students' science learning outcomes. This research implies that the SETS approach can assist teachers in developing the learning process.

Keywords: SETS Approach, Learning Outcomes, Natural Science

$\begin{array}{lll}\text { History: } & & \text { Publisher: Undiksha Press } \\ \text { Received } & \text { : April 19, } 2021 & \text { Licensed: This work is licensed under } \\ \text { Revised } & \text { : April 21, 2021 } & \text { a Creative Commons Attribution 3.0 License } \\ \text { Accepted } & \text { : June 29, 2021 } & \text { Published } \\ \text { : July 25, 2021 } & \end{array}$

\section{Introduction}

Natural Sciences (IPA) is systematic and organized knowledge regularly, which the use is generally limited to the natural phenomenon, and is a collection of the result of observations and experiments data (Maison et al., 2020; Rusli et al., 2020). Natural sciences in a systematic and coherent manners through the discovery process using the scientific method (Anif et al., 2020; Desnita \& Susanti, 2017). This implies that science does not only emphasizes on the mastery of a knowledge collection in the form of facts, concepts, or principles, but it also as discovery process. Science learning essentially emphasizes on providing direct experience to develop competence so that the students are able to explore and understand the natural surroundings scientifically (Fartina et al., 2019; Seruni et al., 2020). Science in elementary schools aims to train and develop knowledge and critical 
thinking skills in solving problems related to environmental science and the relationship between science, environment, technology and society (Lai et al., 2019; Puspasari et al., 2020).

Science learning emphasizes the use of science in everyday life, so that there is a balance between theory and application in everyday life to facilitate understanding and providing solutions to problems that arise in the surrounding environment (Haryono, 2020; Subali et al., 2019; R. B. Toma et al., 2019). Science learning should be designed and implemented as a way of finding out and doing things that could help the students to understand natural phenomena in depth (Huang et al., 2020; Margunayasa et al., 2019). Science is directed to find out and act thus it could help students to gain a deeper understanding of the natural surroundings (Kurniawati et al., 2017; Radu Bogdan Toma \& Greca, 2018). One of the important factors that could support the success of the science learning process in elementary schools is the selection of learning approaches (Century et al., 2020; Huang et al., 2020). By the presence of appropriate learning approach, especially in science learning, it would be able to optimize learning outcomes because approach applied by teachers to the learning process is one of the external factors that could affect students' learning outcomes (Kumala et al., 2020; Lo et al., 2021).

The current condition came precisely opposite. Based on the observations results in third class SD N 7 Dalung. It was found that the form of science learning still focused on the teacher as the main source of knowledge, then lectures became the main choice of learning strategy. Science lessons were always presented verbally through lecture activities and very minimal students' involvement because students only sitting, silent, listening, taking notes and memorizing, therefore it was less interesting for students and boring which ultimately makes students easily forget the concepts that have been given. The success target of teaching science applied by teachers tends to be more directed so that students were skilled at working on the test questions in textbooks so that students' mastery of concepts is low, process skills and students' scientific attitudes do not grow. In delivering the material the teacher pays less attention to the relationship between the material and the real world of students. As a result, learning science becomes less meaningful. In fact, science learning should be more environmentally oriented. This indirectly has an impact on the low students' science learning outcomes which could be seen from the number of students who have not reached the KKM, which is $64 \%$.

Based on these problems, it was necessary to innovate learning that could involve active students so that learning became more meaningful through the implementation of SETS (Science, Environment, Technology and Society) approach. SETS (Science, Environment, Technology and Society) is a learning that connects the relationship between science, environment, technology and society in every discussion (Firdaus, 2017; Masfuah et al., 2011). The SETS approach is a learning approach that links the four elements of SETS, namely science, environment, technology and society in an integrated manner, therefore learning is not only in the field of science being studied but also connects all elements in those SETS (Ulfah et al., 2020; Zoller, 2013). The SETS approach had stages that could train students' scientific literacy. This is because the SETS approach is oriented on the issues where scientific literacy is also related to the natural science issues (Arnó-Macià \& RuedaRamos, 2011; Yuniastuti, 2015).

The use of SETS approach was considered effective to improve students' learning outcomes, this was proven by previous research, stated that SETS approach had an effect on students' science learning outcomes (Lacka et al., 2021; TucksanunKlahan \& Yuenyong, 2012). The implementation of SETS approach could make students interested in learning, because students know the benefits of science concepts, and even understand the positive and negative impacts of applying technology to the environment and society. The implemetation 
of SETS approach could improve students' Biology learning outcomes (Bettencourt et al., 2011; Nikshad et al., 2021). The learning process with SETS approach presents pragmatic activities in accordance with the problems that were often found in the students' environment so that learning activities would be more meaningful for students. This would have an impact on the students' learning outcomes that will last longer (Komariah et al., 2015; Morrison, 2018). The learning science with the implementation of SETS approach was able to improve learning outcomes, skills and students' being active in each lesson (Fukuda, 2020; Yulistiana, 2015). The implementation of SETS approach had a significant effect on students' learning outcomes on Biology material.

Based on the above explanation, the researchers focused on conducting research with the title, "The Effect of the SETS (Science, Environment, Technology And Society) Approach Implementation on the Science Learning Outcomes of Third Grade Students' of SD N 7 Dalung". The purpose of this study was to determine the significant difference in science learning outcomes between groups of students who were taught through the application of the Science Environment Technology and Society (SETS) approach and students who were taught through conventional learning in third-grade elementary school.

\section{Methods}

This study uses a quasi-experimental design, namely "Nonequivalent Control Group Design". The population in this study were third grade students of SD N 7 Dalung of the academic year 2020/2021, totaling 61 students. The sampling technique used is random sampling. One class is used as an experimental class that will receive learning treatment using the SETS approach, namely class IIIa, which amounts to 29 people, while the other class is used as a control class that will receive direct learning model (DI) treatment, namely class IIIb, which consists of 32 people.

The variables in this study can be grouped into two, namely the independent variable and the dependent variable. The SETS (Science Environment Technology and Society) approach with comparison is conventional learning, while the dependent variable is science learning outcomes. The data obtained in this study are the results of learning science. The data collection method used is the test method, namely the science learning outcome test. In this study, to measure students' science learning outcomes in the cognitive domain, multiple choice tests were used by providing 4 answer choices (a, b, c, and d). Each item is given a score of one if the student can answer correctly and is given a score of zero for students who answer incorrectly. Each item is given a score of one if the student can answer correctly and is given a score of zero for students who answer incorrectly. There were 50 questions on the learning outcomes test with the distribution of questions on $\mathrm{C} 1, \mathrm{C} 2$, and $\mathrm{C} 3$ respectively, namely 20,21, and 10. One question in C2 was tested so that the total questions used in the post-test were 50 questions. sBefore being tested, the content validity of the science learning outcomes test was consulted with two expert judges in the field of science. Furthermore, the instrument was tested to determine the reliability of the test, the validity of the items, the test of differentiating power of the test and the level of difficulty of the test.

In this study, a hypothesis was tested that there was a significant difference in science learning outcomes between groups of students who were taught through the SETS approach and groups of students who were taught through conventional learning in class III SD N 7 Dalung. The research data were analyzed in stages, including: data description, prerequisite test, and hypothesis testing. The prerequisite tests carried out were the normality test of the data distribution, and the homogeneity test of variance. Normality test was carried out on 2 groups of data. To determine the normality of the data using Chi Square analysis, while testing the homogeneity of variance using the $\mathrm{F}$ test from anava Havley. The data analysis technique used for hypothesis testing is statistical analysis technique with pooled variance t- 
test assisted by SPSS 16.0 For Windows program at a significance of 0.05 . Before being analyzed, the data obtained have been tested for normality, homogeneity, and collinearity so that the test can be continued.

\section{Results and Discussion Results}

The results of the calculation of the average value of the experimental group taught through the SETS approach in class III SD N 7 Dalung is 76,47 with a variance of 123,38 and a standard deviation of 11,26. Meanwhile, the average final value of science learning outcomes in the control group which was taught through conventional learning in class III SD N 7 Dalung was 52,64 with a variance of 181,67 and a standard deviation of 14,73. From these data, it is known that the experimental group taught through the SETS approach has a higher average value of science learning outcomes than the control group taught through conventional learning.

Before testing the hypothesis, a prerequisite test is carried out which includes a test for normality of data distribution and a test for homogeneity of variance as follows. First, test the normality of the data distribution using Chi Square at a significance level of $\alpha=0,05$. From the calculation obtained $\chi^{2}$ calculate the score of the experimental group's science learning outcomes of 7,74 . The value of $\chi^{2}$ table with a significance level of $5 \%$ that is 9,49 . Because

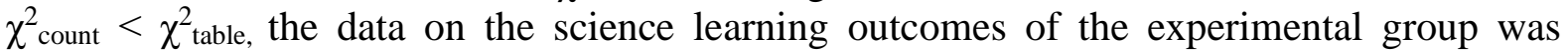
normally distributed. The value $\chi^{2}$ calculate the science learning outcome score for the control group of 4,06 . The value of $\chi^{2}$ table with a significance level of $5 \%$ is 7,82 . Because $\chi^{2}$ count $<$ $\chi^{2}$ table, the control group's science learning score data was normally distributed.

Second, the data homogeneity test for both groups used the F test from Havley. From the analysis results obtained $F_{\text {count }}=1,49$ while $F_{\text {table }}(\alpha=0,05,32,32)=1,76$. This means that $\mathrm{F}_{\text {count }}=1,49<\mathrm{F}_{\text {table }}(\alpha=0,05,32,32)=1,76$ so that the variance of the data on science learning outcomes in the experimental and control classes is homogeneous.

Based on the results of the prerequisite test, namely the normality test of the data distribution and the homogeneity of variance test, it can be seen that the data is normally distributed and has a homogeneous variance. Therefore, to test the hypothesis, it is carried out using parametric statistics, namely the pooled variance t-test. Based on the results of the t-test analysis of the data on students' science learning outcomes, it appears that $t_{\text {count }}=5,862>t_{\text {table }}$ $(\alpha=0,05,64)=2,000$. With these results, it can be concluded that the null hypothesis is rejected. So it can be stated that there is a significant difference in science learning outcomes between groups of students who are taught through the SETS approach and groups of students who are taught through conventional learning in third grade students of SD N 7 Dalung.

From the results of the research data analysis, it was found that the average science learning outcomes in the experimental group was $\bar{X}=76,47$ and the control group was $\bar{X}=$ 52,64 . This shows that science learning in the experimental group takes place optimally. The learning process that occurs in the experimental class takes place actively and meaningfully because in learning students are given the opportunity to gain learning experiences by finding their own concepts being studied. In addition, by applying the SETS approach students will know the importance of the science material being studied to be used in their daily lives so that students are enthusiastic in participating in the learning process and this can also increase students' curiosity about the science material presented by the teacher in the learning process.

While in the control class, which is taught with conventional learning, it is not running optimally. This is because learning tends to be teacher-centered, learning in conventional classes is more adapted to the circumstances and desires of the teacher when teaching students. so that students tend to be only passive and receptive learning actors so that students 
are not active in learning. Based on the t-test obtained $t_{\text {count }}=5,862>t_{\text {table }}(\alpha=0,05,64)=$ 2,000. this means that there is a significant difference in science learning outcomes between students who are taught through the SETS approach and students who are taught using conventional learning. This means that students who are taught using the SETS approach have higher learning outcomes than students who are taught through conventional learning.

\section{Discussion}

Science learning in the experimental class uses the SETS approach, namely learning that connects the concepts being studied with elements of the environment, technology and society. This learning approach has a philosophical foundation to bring students to have an open insight and view science, the environment, technology and society as an inseparable unit (Hu \& Rousseau, 2018; Miehe et al., 2019). By linking the elements in the sians, several advantages will be obtained through the application of the SETS approach, including: 1) training students to think critically, creatively and innovatively supported by wisdom in the development of their reasoning; 2) familiarize students to always think about a cause and effect arising from everything in their environment; 3) Strengthen students' conceptual understanding of the material being studied (Firdaus, 2017; Muzari, 2017; Widiantini et al., 2017).

Remembering that learning science is inseparable from the real world, it is one of the characteristics of science learning (Ho \& Ismawan Prasetia Devi, 2020; Kurniawati et al., 2017; Saripudin et al., 2018). The application of the SETS approach in science learning can make students learn meaningfully, because in learning students can find out the benefits of the science material they learn and apply it in their daily lives (Komariah et al., 2015; Masfuah et al., 2011). The SETS approach compared to other approaches is because the SETS approach is always associated with real events that are often encountered in everyday life (contextual) and comprehensive (integrated between the four SETS components) (Adadan \& Oner, 2018; Firdaus, 2017). In addition, students can also solve problems that exist in their environment and can find out the positive and negative impacts of the application of technology which is a product of science (Fu \& Hwang, 2018; Sert \& Boynueğri, 2017; Summak et al., 2010).

Learning with this approach begins by raising issues or problems around. Furthermore, students are taught about science concepts and principles and finally students are asked to solve problems that exist at the beginning using the science concepts and principles they have learned (Hairida, 2016; Setiawan et al., 2017). Learning with the SETS approach can also increase students' curiosity and enthusiasm in learning because the teacher raises problems or issues that exist around students, so students can learn for real and not only verbally (Ulfah et al., 2020; Yuniastuti, 2015). The SETS approach students are able to have the ability to think globally and solve problems using the concepts they have (Hu \& Rousseau, 2018; Miehe et al., 2019; Rini, 2017).

\section{Conclusion}

The science learning outcomes of students who take lessons with the SETS approach are higher than the average value of science learning outcomes of students who take conventional learning. It can be said that there are significant differences in science learning outcomes between groups of students who are taught through the SETS approach and groups of students who are taught through conventional methods. The SETS approach can improve student learning outcomes. 


\section{References}

Adadan, E., \& Oner, D. (2018). Examining preservice teachers' reflective thinking skills in the context of web-based portfolios: the role of metacognitive awareness. Australian Journal of Teacher Education, 43(11), 26-50. https://doi.org/10.14221/ajte.2018v43n11.2

Anif, S., Sutopo, A., \& Prayitno, H. J. (2020). Lesson study validation: Model for social and natural sciences teacher development in the implementation of national curriculum in Muhammadiyah schools, Indonesia. Universal Journal of Educational Research, 8(1), 253-259. https://doi.org/10.13189/ujer.2020.080132

Arnó-Macià, E., \& Rueda-Ramos, C. (2011). Promoting reflection on science, technology, and society among engineering students through an EAP online learning environment. Journal of English for Academic Purposes, 10(1). https://doi.org/10.1016/j.jeap.2010.12.004

Bettencourt, C., Velho, J. L., \& Almeida, P. A. (2011). Biology teachers' perceptions about Science-Technology-Society (STS) education. Procedia - Social and Behavioral Sciences, 15. https://doi.org/10.1016/j.sbspro.2011.04.262

Century, J., Ferris, K. A., \& Zuo, H. (2020). Finding time for computer science in the elementary school day: a quasi-experimental study of a transdisciplinary problem-based learning approach. International Journal of STEM Education, 7(1). https://doi.org/10.1186/s40594-020-00218-3

Desnita, D., \& Susanti, D. (2017). Science Process Skills-Based Integrated Instructional Materials to Improve Student Competence Physics Education Prepares Learning Plans on Teaching Skills Lectures. Jurnal Penelitian \& Pengembangan Pendidikan Fisika, 3(1), 35. https://doi.org/10.21009/1.03105

Fartina, Hizbi, T., \& Syahidi, K. (2019). Development of Interactive Physics Learning Media Macromedia Flash 8 Based on Straight Motion Material. Journal of Physics: Conference Series, 1539(1). https://doi.org/10.1088/1742-6596/1539/1/012023

Firdaus. (2017). Pengembangan Media Pembelajaran Bervisi Sets Berbantuan Komputer Untuk Meningkatkan Keterampilan Pemecahan Masalah. Indonesian Journal of Science and Education, 1(1), 17-29. https://doi.org/10.31002/ijose.v1i1.417

Fu, Q. K., \& Hwang, G. J. (2018). Trends in mobile technology-supported collaborative learning: A systematic review of journal publications from 2007 to 2016. Computers and Education, 119(July 2017), 129-143. https://doi.org/10.1016/j.compedu.2018.01.004

Fukuda, K. (2020). Science, technology and innovation ecosystem transformation toward society 5.0. International Journal of Production Economics, 220. https://doi.org/10.1016/j.ijpe.2019.07.033

Hairida, H. (2016). The effectiveness using inquiry based natural science module with authentic assessment to improve the critical thinking and inquiry skills of junior high school students. Jurnal Pendidikan IPA Indonesia, 5(2), 209-215. https://doi.org/10.15294/jpii.v5i2.7681

Haryono, H. E. (2020). The Influence of Cooperative Learning Model Type Group Investigation Toward Results of Learning Science Materials of Students. Jurnal Ilmiah Pendidikan Fisika, 4(1), 1. https://doi.org/10.20527/jipf.v4i1.1772

Ho, L., \& Ismawan Prasetia Devi. (2020). A New trend in understanding students' interest in learning science: microetnography. Integrated Science Education Journal (ISEJ), 1(2), 62-66. https://doi.org/10.37251/isej.v1i2.72

$\mathrm{Hu}, \mathrm{X}$. , \& Rousseau, R. (2018). A new approach to explore the knowledge transition path in the evolution of science \& technology: From the biology of restriction enzymes to their application in biotechnology. Journal of Informetrics, 12(3). 
https://doi.org/10.1016/j.joi.2018.07.004

Huang, S.-Y., Kuo, Y.-H., \& Chen, H.-C. (2020). Applying Digital Escape Rooms Infused with Science Teaching in Elementary School: Learning Performance, Learning Motivation, and Problem-Solving Ability. Journal Pre-Proof, 1-46. https://doi.org/10.1016/j.tsc.2020.100681

Komariah, S., Azmi, N., \& Gloria, R. Y. (2015). Penerapan Pendekatan Sets (Science, Environment, Technology, Society) Dalam Pembelajaran Biologi Berbasis IMTAQ Untuk Meningkatkan Hasil Belajar Siswa Pada Konsep Pencemaran Lingkungan Di Sma Negeri 8 Kota Cirebon. Scientiae Educatia: Jurnal Pendidikan Sains, 4(1). https://doi.org/10.24235/sc.educatia.v4i1.481

Kumala, F. N., Setiawan, D. A., \& Shaleha, P. R. (2020). Contextual-Based Animal Encyclopedia: HOTS on Elementary School's Students. 2nd International Conference on Education and Social Science Research (ICESRE 2019) Contextual-Based, 417(Icesre 2019), 132-137. https://doi.org/10.2991/assehr.k.200318.025

Kurniawati, M. W., Anitah, S., \& Suharno, S. (2017). Developing Learning Science Teaching Materials Based on Scientific to Improve Student Learning Outcome in Elementary School. European Journal of Education Studies, 20, 319-330. https://doi.org/10.5281/zenodo.398991

Lacka, E., Wong, T. C., \& Haddoud, M. Y. (2021). Can digital technologies improve students' efficiency? Exploring the role of Virtual Learning Environment and Social Media use in Higher Education. Computers \& Education, 163. https://doi.org/10.1016/j.compedu.2020.104099

Lai, A. F., Chen, C. H., \& Lee, G. Y. (2019). An augmented reality-based learning approach to enhancing students' science reading performances from the perspective of the cognitive load theory. British Journal of Educational Technology, 50(1), 232-247. https://doi.org/10.1111/bjet.12716

Lo, J.-H., Lai, Y.-F., \& Hsu, T.-L. (2021). The Study of AR-Based Learning for Natural Science Inquiry Activities in Taiwan's Elementary School from the Perspective of Sustainable Development. Sustainability, 13(3). https://doi.org/10.3390/su13116283

Maison, M., Haryanto, H., Ernawati, M. D. W., Ningsih, Y., Jannah, N., Puspitasari, T. O., \& Putra, D. S. (2020). Comparison of student attitudes towards natural sciences. International Journal of Evaluation and Research in Education, 9(1), 54-61. https://doi.org/10.11591/ijere.v9i1.20394

Margunayasa, I. G., Dantes, N., Marhaeni, A. A. I. N., \& Suastra, I. W. (2019). The Effect of Guided Inquiry Learning and Cognitive Style on Science Learning Achievement. International Journal of Instruction, 12(1), 737-750. https://doi.org/10.29333/iji.2019.12147a

Masfuah, Rusilowati, A., \& Rusilowati, A. (2011). Pembelajaran Kebencanaan Alam Dengan Model Bertukar Pasangan Bervisi Sets Untuk Menumbuhkan Kemampuan Berpikir Kritis Siswa. Pembelajaran Kebencanaan Alam Dengan Model Bertukar Pasangan Bervisi Sets Untuk Menumbuhkan Kemampuan Berpikir Kritis Siswa, 7(2), 115-120. https://doi.org/10.15294/jpfi.v7i2.1083

Miehe, R., Fischer, E., Berndt, D., Herzog, A., \& Horbelt, J. (2019). Enabling bidirectional real time interaction between biological and technical systems: Structural basics of a control oriented modeling of biology-technology-interfaces. Procedia CIRP, 81. https://doi.org/10.1016/j.procir.2019.03.012

Morrison. (2018). Science, Technology, and Society Studies. Encyclopedia of the Anthropocene, 4. https://doi.org/10.1016/B978-0-12-809665-9.10310-6

Muzari, I. (2017). Upaya Meningkatkan Hasil Belajar IPA Melalui Pendekatan SETS pada Siswa Kelas VII MTs Negeri 4 Gunungkidul Tahun Pelajaran 2016/2017. Jurnal 
Pendidikan Madrasah. https://doi.org/10.14421/jpm.2017.22-04

Nikshad, A., Aghlmandi, A., Safaralizadeh, R., Aghebati-Maleki, L., \& Warkiani, M. E. (2021). Advances of microfluidic technology in reproductive biology. Life Sciences, 265. https://doi.org/10.1016/j.1fs.2020.118767

Puspasari, A., Susilowati, I., Kurniawati, L., Utami, R. R., Gunawan, I., \& Sayekti, I. C. (2020). Implementasi Etnosains dalam Pembelajaran IPA di SD Muhammadiyah Alam Surya Mentari Surakarta (Implementation of Ethnoscience in Science Learning at Elementary School of Muhammadiyah Alam Surya Mentari Surakarta). SEJ (Science Education Journal). https://doi.org/10.21070/sej.v3i1.2426

Rini, C. P. (2017). Pengaruh Pendekatan SETS (Science, Environment, Technology And Society) Terhadap Keterampilan Proses Sains Siswa Sekolah Dasar. Pendas: Jurnal Ilmiah Pendidikan Dasar. https://doi.org/10.23969/jp.v2i1.450

Rusli, R., Rahman, A., \& Abdullah, H. (2020). Student perception data on online learning using heutagogy approach in the Faculty of Mathematics and Natural Sciences of Universitas Negeri Makassar, Indonesia. Data in Brief, 29, 105152. https://doi.org/10.1016/j.dib.2020.105152

Saripudin, E., Sari, I. J., \& Mukhtar, M. (2018). Using Macro Flash Animation Media on Motion Material to Improve Learning Achievement for Learning Science in Junior High School. Jurnal Penelitian Dan Pembelajaran IPA, 4(1), 68-75. https://doi.org/10.30870/jppi.v4i1.3316

Sert, N., \& Boynueğri, E. (2017). Digital technology use by the students and english teachers and self-directed language learning. World Journal on Educational Technology: Current Issues, 9(1), 24. https://doi.org/10.18844/wjet.v9i1.993

Seruni, R., Munawaroh, S., Kurniadewi, F., \& Nurjayadi, M. (2020). Implementation of emodule flip PDF professional to improve students' critical thinking skills through problem based learning. Journal of Physics: Conference Series, 1521(4), 1-6. https://doi.org/10.1088/1742-6596/1521/4/042085

Setiawan, Innatesari, D. K., Sabtiawan, W. B., \& Sudarmin, S. (2017). The development of local wisdom-based natural science module to improve science literation of students. Jurnal Pendidikan IPA Indonesia, 6(1), 49-54. https://doi.org/10.15294/jpii.v6i1.9595

Subali, B., Kumaidi, Aminah, N. S., \& Sumintono, B. (2019). Student achievement based on the use of scientific method in the natural science subject in elementary school. Jurnal Pendidikan IPA Indonesia, 8(1), 39-51. https://doi.org/10.15294/jpii.v8i1.16010

Summak, M. S., Bağlıbel, M., \& Samancioğlu, M. (2010). Technology readiness of primary school teachers: A case study in Turkey. Procedia - Social and Behavioral Sciences, 2(2), 2671-2675. https://doi.org/10.1016/j.sbspro.2010.03.393

Toma, R. B., Greca, I. M., \& Orozco Gómez, M. L. (2019). Attitudes towards science and views of nature of science among elementary school sToma, R. B., Greca, I. M., \& Orozco Gómez, M. L. (2019). Attitudes towards science and views of nature of science among elementary school students in terms of gender, cultur. Research in Science and Technological Education, 37(4), 492-515. https://doi.org/10.1080/02635143.2018.1561433

Toma, Radu Bogdan, \& Greca, I. M. (2018). The effect of integrative STEM instruction on elementary students' attitudes toward science. Eurasia Journal of Mathematics, Science and Technology Education, 14(4), 1383-1395. https://doi.org/10.29333/ejmste/83676

TucksanunKlahan, \& Yuenyong, C. (2012). An Analysis of Grade 12 Students' Technological Capability in Learning About Electromagnetics Through Science Technology and Society Approach (STS Approach). Procedia - Social and Behavioral Sciences, 46. https://doi.org/10.1016/j.sbspro.2012.06.390

Ulfah, N., Ibrahim, \& Vlorensius. (2020). Pengaruh Penerapan Pendekatan SETS ( Science , 
Environment, Technology And Society ) Pada Mata Pelajaran IPA Terhadap Literasi Sains Siswa Kelas VII Di SMP Negeri 2 Tarakan. Borneo Journal of Biology Education, 2(1), 24-32. https://doi.org/10.52222/bjbe.v2i1.1737

Widiantini, N. N. A. S., Putra, M., \& Wiarta, I. W. (2017). Model Pembelajaran Sets (Science, Environment, Technology, Society) Berbantuan Virtual Lab Berpengaruh Terhadap Kompetensi Pengetahuan IPA. Journal of Education Technology. https://doi.org/10.23887/jet.v1i2.11776

Yulistiana, Y. (2015). Penelitian Pembelajaran Berbasis SETS (Science, Environment, Technology, And Society) dalam Pendidikan Sains. Formatif: Jurnal Ilmiah Pendidikan MIPA. https://doi.org/10.30998/formatif.v5i1.169

Yuniastuti, E. (2015). Pengaruh Model Pembelajaran SETS (Science, Environment, Technology and Society) Terhadap Hasil Belajar Biologi Siswa Kelas VII SMP Kartika V-1 Balikpapan Tahun Pelajaran 2015/2016. JST (Jurnal Sains Terapan). https://doi.org/10.32487/jst.v1i2.94

Zoller, U. (2013). Science, Technology, Environment, Society (STES) Literacy for Sustainability: What Should it Take in Chem/Science Education? Educación Química, 24(2). https://doi.org/10.1016/S0187-893X(13)72464-9 